PREVENTIVE HEALTHCARE: TOPICAL ISSUES OF HEALTH RISK ANALYSIS

UDC 614.7

DOI: $10.21668 /$ health.risk/2020.2.01.eng

\title{
NEW MECHANISMS FOR REGULATION OF INDUSTRIAL EMISSIONS INTO THE ATMOSPHERE: A CONCEPTUAL LOOK AT PROSPECTS AND PROBLEMS FROM SANITARY-EPIDEMIOLOGICAL POINT OF VIEW
}

\author{
N.V. Zaitseva, I.V. May \\ Federal Scientific Center for Medical and Preventive Health Risk Management Technologies, \\ 82 Monastyrskaya Str., Perm, 614045, Russian Federation
}

The article considers the main aspects of environmental regulation of chemicals emissions into the atmosphere, based on the principles of quotas for individual business entities. It is shown that new approaches to establishing permissible emissions are an important step towards taking into account human health indicators while limiting the negative impact of all types of emission sources. The main positive innovations are the consideration of long-term pollution indicators, verification of calculated data by field measurements and the use of risk assessment methodology when choosing priority substances.

A comparative analysis of the results of emissions despersion simulating and instrumental data (at the environmental monitoring observation points) showed the need to adjust the consolidated databases of emission sources in the territories of the federal "Clean Air" project.

A conceptual scheme is proposed for establishing limits for permissible emissions from the standpoint of ensuring the sanitary and epidemiological well-being of the population.

It is proposed to supplement the normatively fixed algorithm with a number of steps that will ensure not only compliance with established hygienic standards for air quality, but also take into account the consequences of multicomponent pollution specific to each city. Such steps include identifying unacceptable risk zones in the territories, assessing the contribution of each business entities to health risks and assessing the residual risk after the implementation of separate environmental protection measures and the totality of comprehensive plans measures.

The authors indicate that achieving acceptable risk should be supported by epidemiological data on the territory and the results of in-depth biomedical research. The purpose of such studies is to form a reliable evidence base of absence or preservation of public health harm in the conditions of reducing emissions to level of environmental standards.

Keywords: emission sources, summary databases, emission quotas, atmosphere air, risk, health harm.

On November 01, 2019 the Federal Law No. 195-FZ «On performing an experiment on quoting emissions of pollutants and making alterations into some legislative acts existing in the Russian Federation as regards reduction in ambient air pollution» ${ }^{1}$ came into force. 12 cities are planned as experimental grounds; they are included into «Clean air» Federal project that is a part of «Ecology» National pro- ject. Norilsk, Bratsk, Krasnoyarsk, Magnitogorsk, Chita, and other cities are territories with the highest ambient air contamination; population and authorities there pay a lot of social attention to environmental issues, including ambient air contamination. A task a new quoting mechanism has to solve is to achieve an actual decrease in ambient air contamination in these cities during implementa-

(c) Zaitseva N.V., May I.V., 2020

Nina V. Zaitseva - Academician of the Russian Academy of Sciences, Doctor of Medical Sciences, Professor, Scientific Director (e-mail: znv@fcrisk.ru; tel.: +7 (342) 237-25-34; ORCID: https://orcid.org/0000-0003-2356-1145).

Irina V. May - Doctor of Biological Sciences, Professor, Deputy Director responsible for research work (e-mail: may@fcrisk.ru; tel.: +7 (342) 237-25-47; ORCID: https://orcid.org/0000-0003-0976-7016).

${ }^{1}$ On performing an experiment on quoting emissions of pollutants and making alterations into some legislative acts existing in the Russian Federation as regards reduction in ambient air pollution: The RF Federal Law No. 195-FZ. KonsultantPlus. Available at: http: //www.consultant.ru/document/cons_doc_LAW_329955/(10.05.2020) (in Russian). 
tion of «Clean air» Federal project as a part of «Ecology» National project.

Successful accomplishment of the above experiment seems to probably provide grounds for emissions quoting to be applied in all the regions in the country. Given that, it seems vital to consider all aspects of new approaches bearing in mind providing sanitary-epidemiologic welfare of the population.

The Federal Law stipulates implementing the following stage-by-stage algorithm aimed at fundamental improvement of ambient air quality in cities included into the Federal project:

- the $1^{\text {st }}$ stage: (till May 01, 2020) is consolidated calculations of ambient air contamination;

- the $2^{\text {nd }}$ stage (till August 01, 2020) is calculating and assessing health risks caused by exposure to chemicals contained in emissions;

- the $3^{\text {rd }}$ stage (till November 1,2020 ) is stipulating a list of economic entities that are to allow any emissions in strict conformity with directive quotas and to perform compensatory activities;

- the $4^{\text {th }}$ stage (till March 01, 2021) is making alterations into complex activity programs aimed at reducing contaminants emissions into ambient air.

Including a stage that involves health risk assessment is the most significant innovation in the new mechanism as it will allow providing sanitary-epidemiologic welfare of the population. On one hand, it will provide a tool for determining and imposing limits on emissions that are responsible for the greatest medical and demographic losses among popu- lation; on the other hand, it will secure harmonization of approaches to fixing quotas on emissions and give grounds for determining sanitary protection zones. The latter involves health risk assessment fixed in the regulatory documents $^{2,3}$ and has been successfully applied in practice for many years [1-3].

But still, each element in this new system has its significance and each stage makes its contribution into the ultimate result of standardizing.

When we consider consolidated calculations as the first stage in our experiment, we should note that after the Order by the RF State Ecological Committee No. 66 was issued in 1999, many cities in the country (Perm, Voronezh, Lipetsk, Kazan, Nizhnekams, and some others) created and have been keeping consolidated databases; experts there have been performing consolidated dispersion calculations and their results have been applied to solve variable tasks, for example, in the spheres of city development, monitoring, or giving predictions [4-6], including new standards for emissions into ambient air $^{4,5}[6-8]$.

However, practical work revealed that creation of a consolidate database requires extremely thorough formation, system verification, and constant actualization of all data that are put into it. There are several reasons for that.

An economic entity bears full responsibility for making an inventory list of sources that emit hazardous substances into ambient air; according to the existing regulations, in usual situations such a procedure should be accomplished every five years ${ }^{6}$. Even bearing in

\footnotetext{
${ }^{2}$ On approval of Rules for sanitary hygienic zones establishment and use of ground areas located within the boundaries of sanitary hygienic zones. The RF Government Regulation issued on March 03, 2018 No 222 (last edited on December 21, 2018). KonsultantPlus. Available at: http: //www.consultant.ru/document/cons_doc_LAW_292487/ (10.05.2020) (in Russian).

${ }^{3}$ On validating the last edition of sanitary-epidemiologic rules and standards $\overline{2} \cdot 2.1 / 2.1 .1 .1200-03$. Sanitary protection zones and sanitary classification of enterprises, buildings, and other objects: The Order by the RF Chief Sanitary Inspector issued on September 25, 2007 No. 74. Registered in the RF Ministry of Justice on January 25, 2008 No. 10995 (last edited on April 25, 2014). KonsultantPlus. Available at: http: //www.consultant.ru/document/cons_doc_LAW_74669/(30.04.2020) (in Russian).

${ }^{4}$ On applying a system of consolidated calculations when standardizing emissions: The Order by the RF State Ecological Committee issued on February 16, 1999 No. 66. KODEKS: an electronic fund for legal and reference information. Available at: http: //docs.cntd.ru/document/901729767 (30.04.2020) (in Russian).

${ }^{5}$ Completion of the consolidated database on maximum permissible emissions into ambient air in Naberezhnye Chelny for implementing a system aimed at determining calculated background contamination in the city. The report on fulfilling The State Contract No. 14 ME-8c signed on March 25, 2014. IPEN AS RT. Kazan, 2014, 218 p. (in Russian).

${ }^{6}$ On Approval on the procedure for inventories of stationary sources and emissions of hazardous (contaminating) substances into the atmosphere, adjustment, documenting and storage of data obtained during such inventories: the Order by the RF Ministry of national Resources and the Environment issued on August 7, 2018 No. 353. KonsultantPlus. Available at: http: //www.consultant.ru/document/cons_doc_LAW_309693/(30.04.2020) (in Russian).
} 
mind maximum objectivity presumption and ecological responsibility of an economic entity, one should also take into account that:

- those who use natural resources are not obliged to make inventory lists at the same moment; that is, a database is always somewhat different from the actual situation;

- when making inventory lists, economic entities apply different calculation procedures; some of them, even being included into a list of procedures considered to be valid at the moment $^{7}$, are based on parameters and models that were created 10,15 , or even 20 years ago. For example, Methodical guidelines on calculating gross emissions of hazardous chemicals into ambient air for oil processing and petrochemical enterprises (1990); Methodical guidelines on calculating quantitative properties of contaminants emissions into ambient air from basic technological equipment installed at enterprises that manufacture concentrated food... (1987); Specialized procedure for determining quantities of contaminants that are emitted into ambient air due to technological equipment operating at printing enterprises (1990).

As a result, inventory lists created by economic entities can differ significantly from the actual situation; first of all, it comes to a structure of chemical admixtures that are emitted into ambient air. There is practically no document that stipulates spotting out PM10 and PM2.5 fine-dispersed fractions in solid emissions. And at the same time there are data both in domestic and foreign literature sources on occurrence of PM10 and PM2.5 fine-dispersed fractions in emissions from multiple productions [9-12] and on substantial health risks caused by particles with their size being less than $10 \mu \mathrm{m}[13-15]$;

- most procedures are rather poor tools for approximating emissions from non-standard emission sources; admixtures emitted from such sources are often encoded differ- ently and their types fixed for each particular source also differ from each other;

- taking autonomous heating sources into account is also a tedious, complicated and laborconsuming task that requires a lot of organizational efforts and patience. As a rule, these emission sources are stoves and boilers installed in private houses. Data on fuel that is used in households and periods of stove and boilers functioning can be provided only by citizens who are not obliged to submit them and do not bear any responsibility for their correctness;

- when a consolidate database on emissions sources is being created, emissions from motor transport become another problem as their emissions are not stationary in time and correct calculating in this case depends on how precisely intensity and structure of traffic flows on specific sections in traffic networks have been taken into account and what fuels are commonly used in this or that city $[16,17]$. This component requires constant interaction between consolidated database keepers and local authorities bearing in mind that the latter should be genuinely interested in constant and qualitative data exchange.

Section No. 3 in the Rules for accomplishing consolidated calculations ${ }^{8}$ (hereinafter called the Rules) stipulates that there can be a limitation imposed on including data on contaminants emissions into a database. It is envisaged that not less than $95 \%$ of the total emissions from objects included into the state register that keeps records on emissions sources should be considered. But sometimes emissions that are insignificant in their mass can be emitted from sources that are located in close proximity to residential areas; they can exert more significant impacts on the quality of the environment and population health than more powerful but at the same time more distant emission sources. This fact is unfortunately neglected.

\footnotetext{
${ }^{7}$ A list of procedures applied in 2020 to calculate, standardize, and control contaminants emissions into ambient air. Approved by A.O. Martsinovskiy, the MD of «Atmosfera» Scientific Research Institute (Joint-stock company). Saint Petersburg, 2019, 11 p. (in Russian).

${ }^{8}$ Rules for accomplishing consolidated calculations of ambient air contamination including their actualization / approved by the Order of the RF Ministry of Natural Resources and the Environment issued on November 26, 2019 No. 813. KonsultantPlus. Available at: www.consultant.ru/document/cons_doc_LAW_341489/(30.11.2020) (in Russian).
} 
Thus, for example, when a consolidated database was created for Bratsk, there were emissions sources included into it that caused $95.2 \%$ of the total emitted contaminants in the city; but still, it didn't include such sources as «Karat» LLC, «Atlanta» Ltd, «Timoks» LLC, «Alyans» LLC, «Irkustliy vtormet» LLC, «Vostochnosibiskiy vtorchermet» LLC, «Sanitary-technical and electrical mounting plant» joint-stock company, «Bratskiy benzin» LLC, and almost 60 other economic entities that totally emitted almost 6.3 tons per year! And industrial grounds belonging to these economic entities are located directly next to residential areas (Figure 1).

Point 5. «Karat» LLC (15.98 tons/year); point 10. «Alyans» LLC (3.4 tons/year); point 11. JSC tons/year, point 47. «Union Trade» LLC (22.07 tons/year); point 52. MP «DGI»; MO (7.72 tons/year); point 66. «Universal Eco» LLC (6.10 tons/year).

Probably, if we treat a system for ecological standardizing as being fiscal only and primarily oriented at fixing environmental charges, then taking into account economic entities with insignificant emissions is too labor-consuming and not «beneficial» at all. But if we are preoccupied with providing safety and sanitary-epidemiologic welfare of the population, then excessive data including «insignificant» small emission sources should not a priori be excluded from a consolidated database before consolidated calculations are completed. It can be done only as per results of reconnaissance calculations, ground concentrations, and individual and population risks being taken into account basing on a maximally complete database on emission sources.

Quality of a created database on emission sources guarantees that all the subsequent steps are correct; these steps are determining ground concentrations of contaminants; assessing population exposure; assessing and characterizing health risks; selecting priority chemicals and objects for quoting; fixing quotas for specific economic entities; working out activities aimed at reducing emissions. Incorrect or just not very precise assessment of environmental contamination and contributions made by specific emission sources into this contamination can result in inadequate managerial decisions and risks of financial and time losses borne by economic entities or authorities ${ }^{9}$ [18].

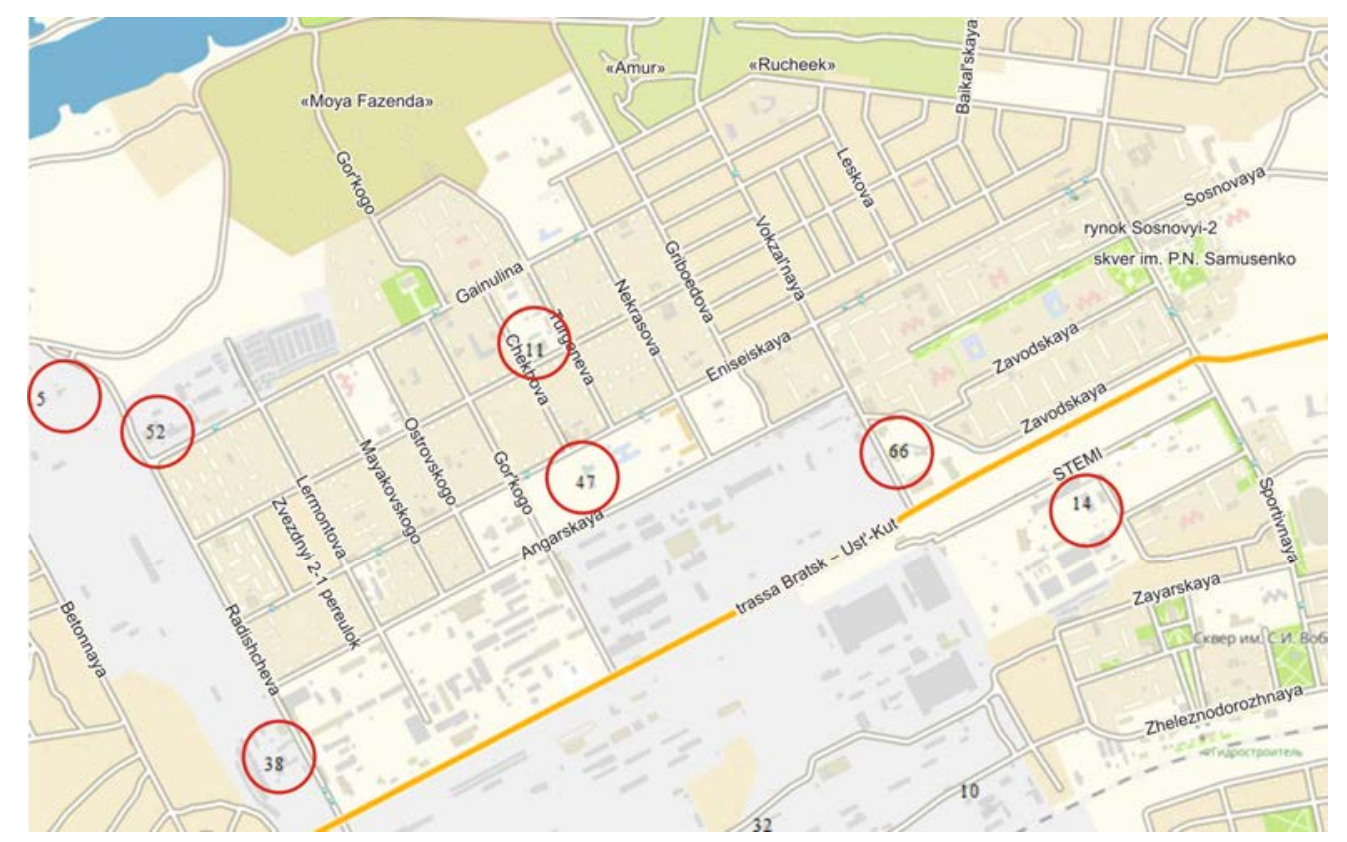

Figure 1. An example showing location of economic entities that were not included into the consolidated database in Bratsk

\footnotetext{
${ }^{9}$ HB 436: 2004. Risk Management Guidelines Companion to AS/NZS 4360. Jointly published by Standards Australia International Ltd. and Standards New Zealand, 2004, 11 p. (in Russian).
} 
Verification of calculation results with data obtained via instrumental research is certainly a way to overcome uncertainties in creation of inventory lists and a consolidated database (Section 7 in the Rules) ${ }^{7}$, and it was first stipulated in a system for fixing maximum permissible emissions. It is assumed that if a database is correct, then dispersion results will satisfactorily coincide with data obtained via ecological monitoring systems. According to items $45-50$ in the Rules, 98-th percentile in the distribution function of a measured substance $\mathrm{q}_{98, \mathrm{j}}$ and single ground concentrations calculated for a point where a monitoring post is located are to be compared as per each contaminant included into conjugated analysis (when short-term concentrations are calculated). When contamination levels are calculated, average annual or average seasonal background concentrations $\mathrm{C}_{\mathrm{r}} \mathrm{j}$ are to be compared with similar calculated values.

Difference between measured and calculated values is determined (1).

$$
\Delta c_{j}=q_{98, j}-c_{j} .
$$

The following condition is checked at each monitoring post as per each substance (2):

$$
\Delta c_{j}>0,25 q_{98, j} .
$$

When the condition (2) is met, it is necessary to analyze why there is this significant difference in values including obtaining more accurate inventory lists, detecting new sources that were probably neglected etc.

Should data correction not result in eliminating significant $\Delta c_{j}$ difference, then values are considered to be authentic, and difference is considered to be due to contaminants being transferred from sources located beyond a territory for which consolidated calculations have been accomplished. In case a value of $\Delta \mathrm{C}$ difference is negative, it is fixed as equal to 0 . The same approaches are applied when verifying averaged data over a year (a season).

Practical work on implementing the $1^{\text {st }}$ stage in the experiment has revealed that overall convergence between calculated and field data is not satisfactory.

Tables 1 and $2^{10}$ give examples of conjugated analysis performed on calculated and instrumental data and conclusions on necessity to make adjustments into initial databases substantiated according to the Rules.

As we can see from the given data, calculated single concentrations of sulfur dioxide are systematically higher than actual contamination (from 2 to 90 times). It is most likely due to drawbacks intrinsic to calculation procedures that are applied to determine emissions, first of all, from energy sources.

Table 1

Instrumental $\left(\mathrm{C}_{\text {measd }}\right)$ and calculated $\left(\mathrm{C}_{\text {calcd }}\right)$ ground concentrations (98-th percentile) of nitrogen dioxide at points where ecological monitoring posts are located

\begin{tabular}{|c|c|c|c|c|c|c|c|}
\hline Post No. & Territory & $\mathrm{C}_{\text {measd }}$ & $\mathrm{C}_{\text {calcd }}$ & $\mathrm{C}_{\text {measd }} / \mathrm{C}_{\text {calcd }}$ & $\mathrm{C}_{\text {measd }}-\mathrm{C}_{\text {calcd }}$ & $\Delta \mathrm{C}$ & $\begin{array}{c}\text { Necessity to make } \\
\text { data more precise }\end{array}$ \\
\hline 7 & Bratsk & 0.009 & 0.26 & 0.03 & -0.251 & 0 & no (?) \\
\hline 8 & Bratsk & 0.012 & 0.171 & 0.07 & -0.159 & 0 & no (?) \\
\hline 11 & Bratsk & 0.007 & 0.055 & 0.13 & -0.048 & 0 & no (?) \\
\hline 1 & Krasnoyarsk & 0.009 & 0.095 & 0.09 & -0.086 & 0 & no (?) \\
\hline 2 & Krasnoyarsk & 0.009 & 0.114 & 0.08 & -0.105 & 0 & no (?) \\
\hline 5 & Krasnoyarsk & 0.022 & 0.223 & 0.10 & -0.201 & 0 & no (?) \\
\hline 7 & Krasnoyarsk & 0.016 & 0.108 & 0.15 & -0.092 & 0 & no (?) \\
\hline 9 & Krasnoyarsk & 0.024 & 0.117 & 0.21 & -0.093 & 0 & no (?) \\
\hline 2 & Chita & 0.048 & 0.102 & 0.47 & -0.054 & 0 & 0 \\
\hline
\end{tabular}

${ }^{10}$ As per data taken from the Report on accomplishing the following activities: Consolidated calculations of ambient air contamination in Bratsk, Krasnoyarsk, Lipetsk, Magnitogorsk, Mednogorsk, Nizhniy Tagil, Novokuznetsk, Norilsk, Omsk, Chelyabinsk, Cherepovets, and Chita, including instrumental research on ambient air contamination. Analyzing representativeness of the existing system for instrumental observations over ambient air quality and ways to improve it. Saint Petersburg: «Atmosfera» Scientific Research Institute (Joint-stock company), 2020 (in Russian). 
New mechanisms for regulation of industrial emissions into the atmosphere: a conceptual look at prospects...

\begin{tabular}{|c|c|c|c|c|c|c|c|}
\hline Post No. & Territory & $\mathrm{C}_{\text {measd }}$ & $\mathrm{C}_{\text {calcd }}$ & $\mathrm{C}_{\text {measd }} / \mathrm{C}_{\text {calcd }}$ & $\mathrm{C}_{\text {measd }}-\mathrm{C}_{\text {calcd }}$ & $\Delta \mathrm{C}$ & $\begin{array}{l}\text { Necessity to make } \\
\text { data more precise }\end{array}$ \\
\hline 3 & Chita & 0.047 & 0.139 & 0.34 & -0.092 & 0 & no (?) \\
\hline 4 & Chita & 0.066 & 0.094 & 0.70 & -0.028 & 0 & no (?) \\
\hline 5 & Chita & 0.049 & 0.196 & 0.25 & -0.147 & 0 & no (?) \\
\hline 6 & Chita & 0.043 & 0.124 & 0.35 & -0.081 & 0 & no (?) \\
\hline 1 & Cherepovets & 0.006 & 0.251 & 0.02 & -0.245 & 0 & no (?) \\
\hline 2 & Cherepovets & 0.034 & 0.254 & 0.13 & -0.220 & 0 & no (?) \\
\hline 31 & Magnitogorsk & 0.079 & 0.09 & 0.88 & -0.011 & 0 & no (?) \\
\hline 33 & Magnitogorsk & 0.03 & 0.06 & 0.50 & -0.030 & 0 & no (?) \\
\hline 34 & Magnitogorsk & 0.077 & 0.16 & 0.48 & -0.083 & 0 & no (?) \\
\hline 35 & Magnitogorsk & 0.087 & 0.08 & 1.09 & 0.007 & 0 & no (?) \\
\hline 36 & Magnitogorsk & 0.092 & 0.13 & 0.71 & -0.038 & 0 & no (?) \\
\hline 2 & Novokuznetsk & 0.075 & 0.179 & 0.42 & -0.104 & 0 & no (?) \\
\hline 9 & Novokuznetsk & 0.023 & 0.207 & 0.11 & -0.184 & 0 & no (?) \\
\hline 10 & Novokuznetsk & 0.049 & 0.345 & 0.14 & -0.296 & 0 & no (?) \\
\hline 19 & Novokuznetsk & 0.094 & 0.276 & 0.34 & -0.182 & 0 & no (?) \\
\hline 2 & Omsk & 0.008 & 0.224 & 0.04 & -0.216 & 0 & no (?) \\
\hline 5 & Omsk & 0.013 & 0.225 & 0.06 & -0.212 & 0 & no (?) \\
\hline 7 & Omsk & 0.010 & 0.368 & 0.03 & -0.358 & 0 & no (?) \\
\hline 26 & Omsk & 0.100 & 0.162 & 0.62 & -0.062 & 0 & no (?) \\
\hline 27 & Omsk & 0.020 & 0.295 & 0.07 & -0.275 & 0 & no (?) \\
\hline 29 & Omsk & 0.009 & 0.835 & 0.01 & -0.826 & 0 & no (?) \\
\hline 3 & Norilsk & 1.04 & 5.53 & 0.19 & -4.490 & 0 & no (?) \\
\hline 4 & Norilsk & 0.770 & 5.90 & 0.13 & -5.130 & 0 & no (?) \\
\hline 11 & Norilsk & 0.720 & 4.89 & 0.15 & -4.170 & 0 & no (?) \\
\hline
\end{tabular}

Table 2

Instrumental $\left(\mathrm{C}_{\text {measd }}\right)$ and calculated $\left(\mathrm{C}_{\text {calcd }}\right)$ ground concentrations (98-th percentile) of hydrogen sulfide at points where ecological monitoring posts are located

\begin{tabular}{|c|c|c|c|c|c|c|c|}
\hline Post No. & Territory & $\mathrm{C}_{\text {measd }}$ & $\mathrm{C}_{\text {calcd }}$ & $\mathrm{C}_{\text {measd }} / \mathrm{C}_{\text {calcd }}$ & $\mathrm{C}_{\text {measd }}-\mathrm{C}_{\text {calcd }}$ & $\Delta \mathrm{C}$ & $\begin{array}{l}\text { Necessity to make } \\
\text { data more precise }\end{array}$ \\
\hline 2 & Bratsk & 0.0060 & 0.0001 & 60.00 & 0.0059 & 0.0015 & yes \\
\hline 3 & Bratsk & 0.0060 & 0.0022 & 2.73 & 0.0038 & 0.0015 & yes \\
\hline 7 & Bratsk & 0.0060 & 0.0001 & 66.67 & 0.0059 & 0.0015 & yes \\
\hline 8 & Chita & 0.0220 & 0.000003 & 733.33 & 0.0220 & 0.0055 & yes \\
\hline 11 & Chita & 0.0170 & 0.0001 & 340.00 & 0.0170 & 0.0043 & yes \\
\hline 1 & Cherepovets & 0.0060 & 0.0060 & 1.00 & 0.0000 & 0.0015 & no \\
\hline 2 & Cherepovets & 0.0060 & 0.0022 & 2.73 & 0.0038 & 0.0015 & yes \\
\hline 5 & Cherepovets & 0.0060 & 0.0012 & 5.13 & 0.0048 & 0.0015 & yes \\
\hline 7 & Cherepovets & 0.0060 & 0.0024 & 2.50 & 0.0036 & 0.0015 & yes \\
\hline 9 & Magnitogorsk & 0.0080 & 0.0009 & 9.09 & 0.0071 & 0.0020 & yes \\
\hline 8 & Magnitogorsk & 0.0080 & 0.0005 & 16.00 & 0.0075 & 0.0020 & yes \\
\hline 2 & Magnitogorsk & 0.0090 & 0.0008 & 11.11 & 0.0082 & 0.0023 & yes \\
\hline 3 & Magnitogorsk & 0.0370 & 0.0011 & 33.64 & 0.0359 & 0.0093 & yes \\
\hline 4 & Novokuznetsk & 0.0060 & 0.0017 & 3.53 & 0.0043 & 0.0015 & yes \\
\hline 5 & Novokuznetsk & 0.1560 & 0.1080 & 1.44 & 0.0480 & 0.0390 & yes \\
\hline 6 & Omsk & 0.0060 & 0.0017 & 3.53 & 0.0043 & 0.0015 & yes \\
\hline 1 & Omsk & 0.0060 & 0.0060 & 1.00 & 0.0000 & 0.0015 & no \\
\hline 2 & Omsk & 0.0060 & 0.0023 & 2.61 & 0.0037 & 0.0015 & yes \\
\hline 3 & Omsk & 0.0060 & 0.0040 & 1.50 & 0.0020 & 0.0015 & yes \\
\hline 5 & Omsk & 0.0060 & 0.0011 & 5.45 & 0.0049 & 0.0015 & yes \\
\hline 31 & Norilsk & 0.0700 & 0.0370 & 1.89 & 0.0330 & 0.0175 & yes \\
\hline 33 & Norilsk & 0.0700 & 0.0340 & 2.06 & 0.0360 & 0.0175 & yes \\
\hline 34 & Norilsk & 0.0700 & 0.0400 & 1.75 & 0.0300 & 0.0175 & yes \\
\hline
\end{tabular}




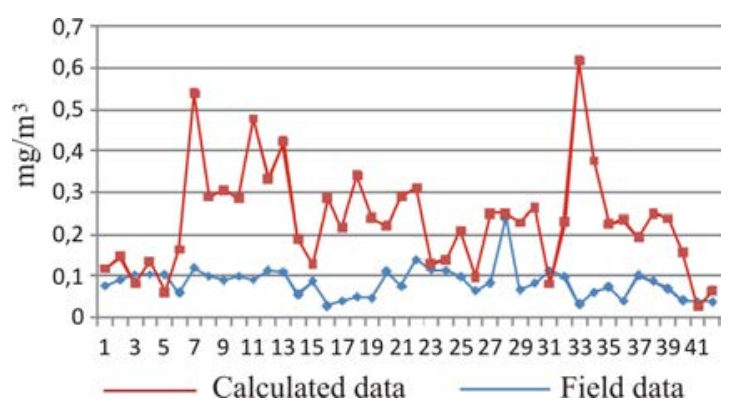

Figure 2. Compared data on calculated and measured single (q98) concentrations of nitrogen dioxide at points where Rosgidromet's monitoring posts are located in cities included into «Clean air» Federal project

However, according to approaches fixed in the regulatory document ${ }^{7}$ this situation doesn't require any adjustments made into initial data. But at the same time, if calculated data are applied as an information basis for assessing exposure and health risks, we can be sure there will be substantial «overestimating» and risks levels will be overstated. The latter will be used for determining unacceptable risk levels and will unavoidably result in making recommendations on reducing ecological burdens for populations and implementing additional air protecting activities by industrial enterprises. In this case, financial costs will hardly be justified bearing in mind potentially prevented damage to health. Assessing correctness of calculated data as per $\mathrm{C}_{\text {measd }} / \mathrm{C}_{\text {calcd }}$ ratio seems easier to understand and more informative and can be used as an additional parameter when making decisions on further actions required to correct inventory lists.

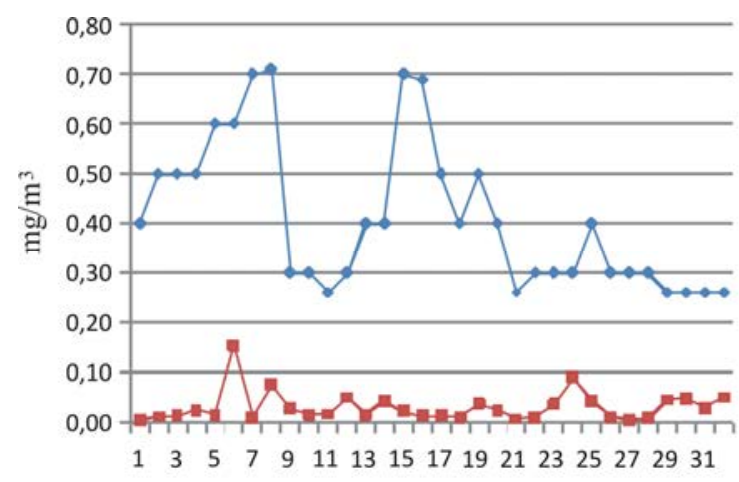

$a$

Calculated data
We should note that the same trend («overstated» calculated levels as compared with actual measured ones) is detected via conjugated analysis of air contamination with nitrogen dioxide (Figure 2). In spite of overall data convergence being rather satisfactory (difference varies from 1.1 to 20 times at some monitoring posts), potential risks aggravation can still be expected.

Even more alerting is a situation when calculated data are substantially lower than measured ones. It was detected for carbon oxide in Chita (measured concentrations are up to 11.5 times higher than calculated ones), Omsk (up to 9 times higher), and Novokuznetsk (up to 6 times higher).

Calculated and field data on dusts (particulate matter) are practically beyond any comparison (Figure 3).

High convergence of the results in this case could hardly be expected to due peculiarities intrinsic to differentiated coding applied for solid emissions during inventories and practically complete absence of differentiated instrumental measuring applied to solid substances in monitoring systems.

The existing situation requires fundamental revision of approaches to taking into account solid components in emissions; it is obligatory to identify and quantitatively determine fine-dispersed PM10 and PM2.5 fractions during inventories as they are the most hazardous for human health.

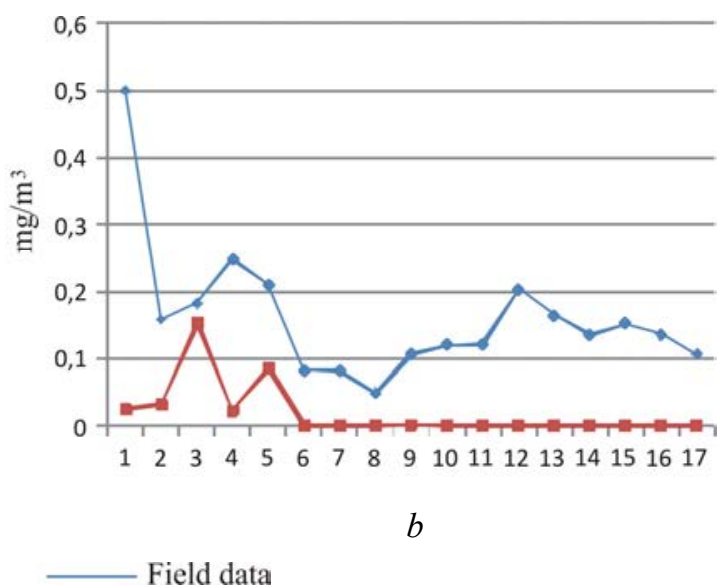

Figure 3. Compared data on calculated and measured single (a) and average annual (b) concentrations of particulate matter at points where Rosgidromet's monitoring posts are located in cities included into «Clean air» Federal project 
Even more significant differences between calculated and field data were detected for specific contaminants. Measured single concentrations were extremely higher than calculated ones at some monitoring posts; for example, hydrogen sulfide concentration was up to 700 times higher (Table 2); hydrogen chloride, up to 180 times higher; phenol, up to 6,000 times higher, etc.

Average annual calculated concentrations of specific chemicals were also lower (by several times) than measured ones practically at all monitoring posts.

Should calculated data be applied to assess population health risks in this situation, it will unavoidably result in inadequate decisions on emission quoting.

But still, making adjustments into inventory lists and improving initial databases applied for calculations seems to be merely a technical and/or organizational task. As certain experience has been accumulated in creating consolidated databases, these problems can be and most likely will be eliminated or minimized.

Involving a greater number of points where field data are collected for further verification of calculated ones can be an instrument for improving initial data quality. It will allow more rapid and precise identification of reasons for data not being convergent and will help making proper corrections into parameters of sources. To solve these tasks, it seems advisable to use not only data obtained via ecological monitoring systems but also data collected within social and hygienic monitoring systems.

Therefore, creation of a complete and correct database on parameters of emissions sources that influence ambient air quality on a given territory is the first and the most significant step in implementing the whole new system for emission quoting.

The next significant step in fixing standards for permissible emissions is selecting priority contaminants, objects for quoting, and control points for emission quoting.

Priority substances that are subject to quoting are contaminants that, when emitted into the atmosphere, influence violation of hygienic standards for ambient air quality and create health risks on territories included into the experiment (item 1 in Clause 3 of the Federal Law 194-FZ) ${ }^{1}$.

It is for the first time when risk assessment results are fixed in legislation as an element in a system for standardizing emissions. At the same time, a dozen or even more admixtures can make their contributions into health risks and shares belonging to some can be really insignificant. It seems relevant to provide precise criteria for fixing a minimal contribution made by a contaminant into unacceptable health risks; any quoting below this minimum level seems unadvisable and, consequently, inefficient. Due to determination of priority contaminant lists being a responsibility borne by the Federal Service for Surveillance over Consumer Rights Protection and Human Well-being (item 4 in Clause 4 of the Federal Law 194-FZ) ${ }^{1}$ it seems important to provide scientific substantiation and methodical support for clear and unified procedures and criteria applied to select priority substances for further accounting. And when substantiating a list of priority contaminants, it is advisable to take into account not only calculated risks but also results obtained via epidemiologic research, and in some cases also evidence proving that damage has been done to human health. A methodical document provided by Rospotrebnadzor is truly significant due to priority contaminants selection being directly related to calculating contributions made by specific economic entities into occurring health risks; it can be used as grounds for creating a list of objects that are subject for quoting (item 5.2 in the Rules).

Unfortunately, the most significant components in the quoting system, namely selecting criteria for standardizing and control points parameters of which are used as a toll to substantiate quoting, do not take into account health risk parameters. According to item 3.2 in the Rules, "control points are points... where longterm... or single maximum calculated concentrations of priority contaminants... violate the standards fixed for ambient air quality (hereinafter called MPC)». According to item 4.2, «To assess whether ambient air contamination 
complies... one should use maximum permissible concentrations of contaminants in ambient air...». Therefore, risk assessment results are just abandoned since a target criterion in quoting is compliance with MPC and not achieving acceptable health risk levels.

The Rules do not stipulate any procedure for assessing residual health risks after emission quotas have been fixed. Accordingly, obtained results will not stimulate economic entities to reduce contamination down to acceptable risk levels. And we should note that if there is longterm multi-components contamination, health risks and additional mortality and morbidity among population can occur even in case a concentration of each specific component doesn't violate hygienic standards; therefore, socially significant results may not be achieved.

Bearing in mind strategic goals set by the RF President and the Government that clearly define population health and an increase in life expectancy as top state priorities, it seems extremely vital to be guided exactly by criteria related to population health, health risks or damage parameters, when fixing standards for hazardous impacts exerted on the environment. Such criteria can provide a clearer idea of potential medical and demographic losses than MPC.

The Figure 4 shows a conceptual scheme that can be applied to fix standards for permissible emissions bearing in mind providing sanitary-epidemiologic welfare of the population. All the basic components in the system that is fixed in the Federal Law on quoting are preserved.

But still, we recommend adding several steps into the fixed algorithm; they will allow not only providing compliance with the hygienic standards fixed for ambient air quality but also taking into account effects produced on population health by multi-component contaminations that is specific for each given city. These steps are:

- spotting out zones where health risks are unacceptable on each territory. Such zones do not always coincide with zones where ground concentrations of certain contaminants are the highest hence risk assessment usually takes into account aggregated impacts exerted by all the substances that influence the same organs and systems and reference levels of each component;
- assessing contributions made by specific economic entities into health risks. This additional criterion can be taken into account when priority objects for quoting are being determined. Primarily, it is necessary to reduce emissions from objects that create the highest health risks; it will allow reliable achieving acceptable risk levels using an optimal set of activities;

- assessing residual risks after accomplishing either specific environmental activities or a whole set of measures stipulated in complex programs. The step will allow assessing whether activates have been productive and efficient as per acceptable risk criteria;

- accomplishing profound epidemiologic and medical-biological research, with its aim being creation of a reliable evidential database proving absence or occurrence of damage to population health including a situation when emissions have been reduced to acceptable levels fixed in ecological standards.

The step seems truly vital due to risks being a calculated and predictive value in spite of the whole system being guided by the health risks assessment methodology. Reference concentrations that are safety criteria for a given admixture are not always adequate to specific conditions occurring due to multi-component and long-term contamination. Socioeconomic conditions, peculiarities related to population genotypes, etc., also make their adjustments into actual exposure levels.

To make calculation estimates more precise, it is advisable to perform epidemiologic and profound medical research in order to assess actual realization of risks and creation of evidential databases that prove there has been damage to health caused by combined aerogenic exposure [19-21], In some cases specific research can detect risk factors that are typical for a given territory only and can't be revealed via calculations [22]. It is extremely important for decision-makers at all management levels as it allows them to avoid situations in which risks aggravation leads to unnecessary expenses on air-protecting activities and risks underestimation results in absence of positive effects for population health expected due to the Federal project implementation. 


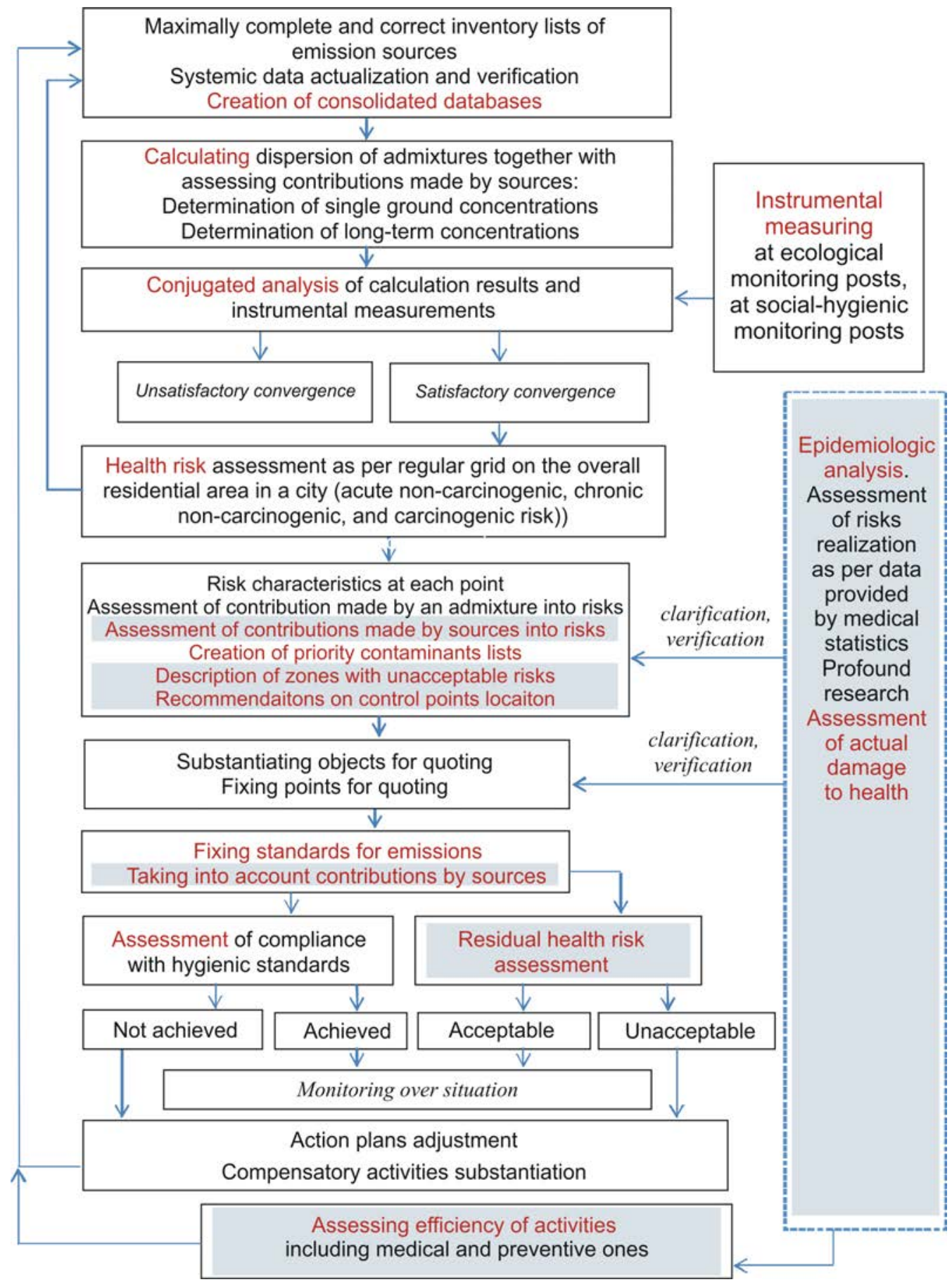

Figure 4. Conceptual diagram. Fixing standards for permissible emissions bearing in mind providing sanitary-epidemiologic welfare of the population

Elements that are not included into a conventional standardizing procedure are shaded

Conclusion. New approaches to standardizing contaminants emissions into ambient air are undoubtedly a significant step towards taking population health into account when imposing limits on negative impacts exerted by emission sources of any type. Basic positive innovations are taking into account long-term contamination and applying risk assessment methodology when selecting priority contaminants.

According to the Federal Law 195-FZ quotas are to be fixed for substances that are considered «priority» ones; given that, it is necessary to scientifically substantiate and methodically determine clear and unified methods and criteria for selecting priority substances for further ac- 
counting, including those based on risk assessment, epidemiologic research, and an evidential base proving detected damage to health.

Creation consolidated databases for a whole territory should be thorough and a process should be controlled by both authorized Rospotrebnadzor bodies that verify parameters of emissions sources located at industrial objects and by local authorities that verify parameters of emissions from mobile sources and emissions from private households (stoves and boilers). Besides qualitative collection of initial data, it is also necessary to organize work on systematic and persistent actualization of a database and on verifying parameters of emissions sources with data obtained via field observations.

Differentiation of solid components with spotting out PM10 and PM2.5 fine-dispersed fractions as the most hazardous ones should become the most significant element in emissions accounting.

Substantiating the selection of control points for emissions quoting seems to be the most vital task. Prior to any selection, admixtures dispersion should be calculated and all variants of unfavorable meteorological conditions should be taken into account; these conditions should be preset for sources with different heights; it is also necessary to perform spatial assessment of health risks distribution, both individual and population ones.

Within the experiment it seems vital to test both the algorithm and criteria for substantiating priority object for quoting taking into account detected zones with unacceptable risks on a given territory and assessing contributions made by economic entities into occurring health risks.

Assessment of residual risks after either specific environmental activates or an overall set of them stipulated in complex programs have been accomplished should become an obligatory element in a system used for standardizing permissible emissions.

Achieving acceptable risks should be supported by epidemiologic data collected on a given territory and results obtained via profound medical and biological examinations aimed at creating a reliable evidential base that proves absence or persistence of damage to health after emissions have been reduced down to acceptable target levels fixed in ecological standards.

Funding. The paper has been accomplished within the fulfillment of tasks set by «Clean air» federal project as a part of «Ecology» national project.

Conflict of interests. The authors state that there is no any conflict of interest.

\section{References}

1. Boev V.M., Kireev A.A., Osiyan S.A., Karpenko I.L., Boev V.V. Practical use of a methodology for assessing an aerogenic risk to human risk in the substantiation of a control area. Gigiena $i$ sanitariya, 2009, no. 4, pp. 82-83 (in Russian).

2. Sabirova Z.F., Vinokurov M.V. The actual issues of evaluation of risks for population health under substantiation of size of buffer zone of enterprises. Zdravookhranenie Rossiiskoi Federatsii, 2015, vol. 59, no. 5 pp. 18-22 (in Russian).

3. Kokoulina A.A., Balashov S.Yu., Zagorodnov S.Yu., Koshurnikov D.N. Hygienic evaluation of objects concerning extraction, preparation and primary processing of oil, considering health risk parameters. Meditsina truda i promyshlennaya ekologiya, 2016, no. 12, pp. 34-38 (in Russian).

4. Volkodaeva M.V., Kanchan Y.S. To the question of application of combined calculation of the indexes of pollutant emissions impact when managing atmospheric air quality. Problemy regional'noi ekologii, 2008, no. 6, pp. 127-131 (in Russian).

5. Shagidullin R.R., Shagidullina R.A., Kamalov R.I. Summary calculations of air pollution as an ecological safety support tool. Vestnik NTsBZhD, 2015, vol. 123, no. 1, pp. 130-133 (in Russian).

6. Kostyleva N.V., Gileva T.E., Oputina I.P Summary calculations of pollution of atmospheric air. Antropogennaya transformatsiya prirodnoi sredy, 2017, no. 3, pp. 106-107 (in Russian).

7. Nedre A.Yu., Azarov V.N., Nedre Yu.A. Application of multiple source calculation of air pollution level when finding solutions for city planning withing the frameworks of public transport scheme optimization. Internet-Vestnik VolgGASU, 2012, vol. 22, no. 2, p. 18 (in Russian). 
8. Shagidullin A.R., Magdeeva A.R., Gabdrakhimova V.A. Primenenie svodnykh raschetov dlya analiza korrektnosti ustanovlennykh normativov vybrosov zagryaznyayushchikh veshchestv $\mathrm{v} g$. Nizhnekamsk [Application of summary calculations for the analysis of the correctness of the established standards for emissions of pollutants in Nizhnekamsk]. XXIV Tupolevskie chteniya (shkola molodykh uchenykh): sbornik materialy Mezhdunarodnoi molodezhnoi nauchnoi konferentsii: v 6 t. 2019, pp. 494-496 (in Russian).

9. Soriano A., Pallarés S., Vicente A.B., Sanfeliu T., Jordán M.M. Assessment of the main sources of $\mathrm{PM}_{10}$ in an industrialized area situated in a Mediterranean Basin. Fresenius Environmental Bulletin, 2011, vol. 20, no. 9 A, pp. 2379-2390.

10. Wang Y., Peng L., Wang Y., Zhang T., Liu H., Mou L. Characteristics of chemical components in $\mathrm{PM}_{2.5}$ from the coal dust of power plants. Environ. Sci., 2016, vol. 37, pp. 60-65.

11. Zagorodnov S., Kokoulina A., Popova E. Studying of component and disperse structure of dust emissions of metallurgical complex enterprises for problems of estimation the population exposition. Izvestiya Samarskogo nauchnogo tsentra Rossiiskoi akademii nauk, 2015, vol. 17, no. 5-2 pp. 451-456 (in Russian).

12. Pope C.A. Epidemiology of fine particulate air pollution and human health: biologic mechanisms and who's at risk? Environmental Health Perspectives, 2000, vol. 108, no. 4, pp. 713-723.

13. Putaud J.P., Van Dingenen R., Alastuey A., Bauer H., Birmili W., Cyrys J., Flentje H., Sandro F. [et al.]. A European aerosol phenomenology - 3: Physical and chemical characteristics of particulate matter from 60 rural, urban, and kerbside sites across Europe. Atmospheric Environment, 2010, vol. 44, no. 10, pp. 1308-1320.

14. Polichetti G., Cocco S., Spinali A., Trimarco V., Nunziata A. Effects of particulate matter $\left(\mathrm{PM}_{10}, \mathrm{PM}_{2.5}\right.$ and $\left.\mathrm{PM}_{1}\right)$ on the cardiovascular system. Toxicology, 2009, vol. 261, no. 1-2, pp. 1-8. DOI: 10.1016/j.tox.2009.04.035

15. Ermachenko A.B., Krotov V.S. Gigienicheskoe obosnovanie tselesoobraznosti normirovaniya vliyaniya vzveshennykh chastits $\mathrm{v}$ atmosfernom vozdukhe $\mathrm{s}$ uchetom ikh fraktsionnogo sostava [Hygienic rationale for rationing the effect of suspended particles in atmospheric air, taking into account their fractional composition]. Gigiena naselennykh mest, 2013, no. 62, pp. 46-49 (in Russian).

16. Badalyan L.K., Kurdjukov V.N., Aleynikova A.M. The Theoretical Bases of Factual Motor-Vehicle Emissions Accounting System. Bezopasnost' zhiznedeyatel'nosti, 2013, vol. 149, no. 5, pp. 31-37 (in Russian).

17. Guseinov A.I., Tagizade A.G., Dzhavadov N.G. Research of urban atmospheric pollution due to emissions from autotransport at the controlled roads crossings. Ekologiya urbanizirovannykh territorii, 2015, no. 4, pp. 67-71 (in Russian).

18. Oganyan N.G. Measurement uncertainty and corresponding risk of false decisions. Journal of Physics: Conference Series, 2019, vol. 1420, 3 p.

19. Identifying the environmental cause of disease: how should we decide what to believe and when to take action? UK, London: Academy of Medical Sciences. The Academy of Medical Science. Available at: http://www.acmedsci.ac.uk/index.php (18.05.2020).

20. Zaitseva N.V., May I.V., Kleyn S.V., Khankhareev S.S., Boloshinova A.A. Scientific and methodological aspects and practical experience for the formation of the evidential base of hazard to health in the population in the zone of influence of waste from the past economic activity. Gigiena $i$ sanitariya, 2017, vol. 96, no. 11, pp. 1038-1044 (in Russian).

21. Brunekreef B. Environmental Epidemiology and Risk Assessment. Toxicology Letters, 2008, vol. 180, no. 2, pp. 118-122. DOI: 10.1016/j.toxlet.2008.05.012

22. Maklakova O.A., Zaitseva N.V., Ustinova O.Yu. Osobennosti formirovaniya sochetannoi patologii $\mathrm{u}$ detei $\mathrm{v}$ usloviyakh aerogennogo vozdeistviya tekhnogennykh khimicheskikh faktorov [Features of the formation of combined pathology in children under the conditions of aerogenic exposure to technogenic chemical factors]. Aktual'nye voprosy analiza riska pri obespechenii sanitarno-epidemiologicheskogo blagopoluchiya naseleniya $i$ zashchity prav potrebitelei: sbornik materialov IX Vserossiiskoi nauchno-prakticheskoi konferentsii s mezhdunarodnym uchastiem, Perm, 2019, pp. 423-428 (in Russian).

Zaitseva N.V. May, I.V. New mechanisms for regulation of industrial emissions into the atmosphere: a conceptual look at prospects and problems from sanitary-epidemiological point of view. Health Risk Analysis, 2020, no. 2, pp. 4-15. DOI: 10.21668/health.risk/2020.2.01.eng

Received: 03.05.2020

Accepted: 13.06 .2020

Published: 30.06 .2020 